\title{
Changes in the volume and histology of endometriosis foci in rats treated with copaiba oil (Copaiferalangsdorffii) ${ }^{1}$
}

\author{
Mudanças no volume e histologia do foco de endometriose em ratas tratadas com óleo de \\ Copaíba (Copaiferalangsdorffii)
}

\begin{abstract}
João Nogueira NetoI, Márcio Jorge de Souza Lindoso", Laura Fernandes Coelho", Rafael Antonio Freire Carvalho", Taciana Gabrielle Pinheiro de Moura Rodrigues ${ }^{\mathrm{II}}$, Ana Gisélia Portela de Araújo ${ }^{\mathrm{III}}$, Manuel João Batista Castelo Girão ${ }^{\mathrm{IV}}$, Eduardo Schorv
\end{abstract}

\begin{abstract}
${ }^{\mathrm{I}} \mathrm{MD}$, Fellow PhD degree, Federal University of Sao Paulo (UNIFESP), Unit of Endometriosis of HU-UFMA, Brazil. Design the protocol, involved with technical procedures, responsible for manuscript writing, responsible for intellectual and scientific content of the study, supervised all phases of the study, and provided guidelines for the surgical interventions.

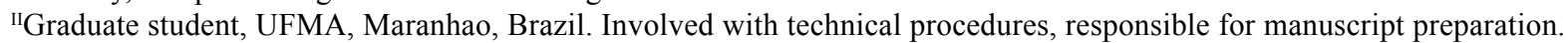

IIIMD, HUUFMA, Maranhao, Brazil. Macroscopic and histopathological examinations.

${ }^{\text {IV }} \mathrm{PhD}$, Department of Ginecology, Paulista School of Medicine, Federal University of Sao Paulo (EPM-UNIFESP), Brazil. Responsible for intellectual and scientific content of the study, critical revision, provide guidelines for the surgical interventions.

${ }^{\mathrm{v}} \mathrm{PhD}$, Affiliate Professor, UNIFESP, Head of Unit of Pelvic Pain and Endometriosis, EPM-UNIFESP, Sao Paulo, Brazil. Responsible for acquisition and interpretation of data, statistical analysis, helped with technical procedures, collection and processing of study informations, provide guidelines for the surgical interventions
\end{abstract}

\begin{abstract}
PURPOSE: The aim of this study was to analyze the changes that occur in rats with experimental endometriosis after treatment with copaiba oil.

METHODS: Experimental endometriosis was induced in rats. The experimental group received copaiba oil (Copaiferalangsdorffii) orally $(0.63 \mathrm{mg} /$ day $)$, and the control group received a $0.9 \%$ sodium chloride solution orally $(1 \mathrm{ml} / 100 \mathrm{~g}$ of body weight/day). Both groups were treated with gavage for 14 days. After this period, the animals were euthanized, and the implant volume was calculated. The autologous transplants were removed, dyed with hematoxylin-eosin, and analyzed by light microscopy.

RESULTS: The average final volumes were significantly different between the groups $(\mathrm{p}=0.007)$. There was a significant increase $(\mathrm{p}=0.012)$ between the initial and final volumes in the control group, whereas treatment with Copaiferalangsdorffii caused a marked reduction in endometrial growth over time $(\mathrm{p}=0.016)$. Histologically, $6 / 11(55.00 \%)$ rats in the experimental group had a well-preserved epithelial layer, and $3(45.00 \%)$ had mildly preserved epithelium. The control group had seven cases $(58.30 \%)$ of well-preserved epithelial cells and five cases $(41.70 \%)$ of mildly preserved epithelial cells ( $p>0.05)$.
\end{abstract}

CONCLUSION: Copaiba oil (Copaiferalangsdorffii) appears to be a promising alternative treatment for endometriosis.

Key words: Phytotherapy. Endometriosis. Drug Therapy. Rats.

\section{RESUMO}

OBJETIVO: O objetivo deste estudo foi analisar as mudanças que ocorreram em ratas com endometrioses experimental tratadas com óleo de copaíba.

MÉTODOS: Foi induzida a endometriose experimental nas ratas. O grupo experimental recebeu óleo de copaíba (Copaiferalangsdorffii) oralmente $(0,63 \mathrm{mg} / \mathrm{dia})$ e o grupo controle recebeu oralmente solução salina $0,9 \%(1 \mathrm{~mL} / 100 \mathrm{~g} / \mathrm{dia})$. Ambos grupos foram tratados por gavagem por 14 dias. Depois desse período, foi realizada a eutanásia dos animais e calculado o volume do implante. Os transplantes autólogos foram removidos, corados com Hematoxilina-eosina e realizada a microscopia óptica.

RESULTADOS: A média final dos volumes foi significativamente diferente entre os grupos $(\mathrm{p}=0,007)$. Houve um aumente significante $(\mathrm{p}=0,12)$ entre o volume inicial e final do grupo controle, enquanto no grupo tratado com Copaiferalangsdorffii causou uma redução acentuada no crescimento endometrial ao longo durante o período $(\mathrm{p}=0,016)$. Histologicamente,6 das $11(55 \%)$ ratas do grupo experimental tinha uma camada epitelial bem preservada e $3(45 \%)$ apresentaram epitélio levemente preservado. O grupo controle apresentou sete casos $(58,3 \%)$ de células epiteliais bem preservadas e cinco casos $(41,7 \%)$ de células epiteliais levemente preservadas $(\mathrm{p}>0,05)$.

CONCLUSÃO: O óleo de copaíba (Copaiferalangsdorffii) parece ser um tratamento alternativo promissor para endometriose. Descritores: Fitoterapia. Endometriose. Quimioterapia. Ratos. 


\section{Introduction}

Endometriosis is a condition that affects $10 \%$ of women, and often causing pelvic pain and infertility. Diagnosis is sometimes difficult and the optimal treatment is yet to come. Some events of the pathophysiology of endometriosis are well known, such as inflammation, immunomodulatory disorders, increased local and systemic oxidative stress, among others. The search for new treatments for endometriosis is justified when interfering in the events mentioned above ${ }^{1}$.

The copaibas are trees in the LeguminosaeCaesalpinoideae family, reaching 25-40 feet tall and can live upto 400 years. Copaiba oil, in biological terms, is a product of excretion or detoxification of the plant organism, and acts as a plant defence against animals, fungi and bacteria ${ }^{2}$. The attributed effects to Copaiba oils in folk medicine are anti-inflammatory, anti-tumour, anti-tetanus, anti-blenorrhagea, as a urinary anti-septic, to treat bronchitis, syphilis, skin diseases, ulcers, as well as for healing wounds ${ }^{3}$.

Some properties of Copaiba oil are well documented in the scientific world, which could justify its use in the treatment of endometriosis. Its anti-inflammatory effect had been observed in the research, which used kaurenoico acid, extracted from Coapiferalangsdorffii, and used in Wistar rats with induced colitis. Furthermore, light microscopy revealed the marked reduction of inflammatory cell infiltration and submucosal oedema formation in the colon segments of rats treated with the test compound ${ }^{4}$. The anti-inflammatory activity was confirmed in a comparative study between oils from Copaiferacearensis, Copaifera reticulate and Copaiferamultijuga in vitro and in vivo ${ }^{5}$. The study indicated that Copaiba oils demonstrate peripheral and central antinociceptive effect and may be useful in the treatment of algesic disorders ${ }^{6}$.

Another study examined the effects of Copaiferalangsdorffii resin on intestinal damage associated with mesenteric ischemia/reperfusion (I/R) in rats. Caused significant attenuations in $\mathrm{I} / \mathrm{R}$ - associated increases of myeloperoxidase, malondialdehyde, catalytic activities and nitrite level. Copaiferalangsdorffii could effectively prevent the I/R-associated depletion of glutathione. The data indicate that the copaiba provided protection against I/R-induced intestinal tissue damage, which appeared to be, at least in part, due to an antioxidant and anti-lipid peroxidation mechanism? ${ }^{7}$.

Antimicrobial activity was revealed through disruption and damage to the cell wall, resulting in the release of cytoplasmic compounds, alterations in morphology, and a decrease in cell volume, indicating that copaiba oil may affect the cell wall. Another effect that suggests anti-cell-proliferation was shown in a study that showed significant activity against the parasite Leishmania amazonensis $^{8}$.

The development of experimental endometriosis in female rats through auto-transplantation techniques prompted research on additional medical treatments for endometriosis. These treatments were analyzed for their efficacy via macroscopic and histological parameters, among others ${ }^{9,10}$.

Because of the known properties of Copaiferalangsdorffii and its relationship to mechanisms involved in the etiopathogeny of endometriosis, the present study aimed to analyze its effects on experimental endometriosis implants in rats.

\section{Methods}

The study was carried out between March and Julyof 2010, using 40 60-day-old (adult) female Wistar rats (Rattus norvegicus albinus), weighing $180-250 \mathrm{~g}$. The rats were obtained from the bioterium of the Federal University of Maranhao (UFMA).

The study was developed in the Experimental Surgery Laboratory of the University Hospital of UFMA, Brazil. Study procedures followed the regulations of the Brazilian Legislation for the use of experimental animals (Arouca Act $\mathrm{n}^{\circ} 11.794 / 2008$ ) and of the Brazilian Animal Experimentation College (COBEA), an institution affiliated with the International Council for Laboratory Animal Science. The study was approved by the Animal Experimentation Ethics Committee (CEEA-UEMA) under protocol number $035 / 2010$.

The animals were grouped four per polypropylene cage $(46 \mathrm{~cm} \times 31 \mathrm{~cm} \times 16 \mathrm{~cm})$ with a stainless steel grid lid and a paper covered floor that was replaced every 48 hours. The animals were divided into four groups and maintained under constant environmental conditions. These including rat rations (PURINA ${ }^{\circledR}$, São Paulo, Brazil) and water ad libitum for seven days for adaptation; noise control; $22^{\circ} \mathrm{C} \pm 2{ }^{\circ} \mathrm{C}$ temperature; $40 \%$ to $60 \%$ relative humidity; and 12/12 hour light/dark cycles.

The autotransplantation technique was performed according to the methodology proposed by Nogueira et al. ${ }^{1}$. Shortly after the midway incision, the uterine horns were identified; fragments of the medium third were resected, immersed in saline solution and cut into $4 \mathrm{~mm}$ by $4 \mathrm{~mm}$ fragments. The fragments were sutured to the mesentery adjacent to the artery that irrigates the cecum, with the serosa faces turned to the peritoneum and the endometrial layer turned to the cavity (Figure 1).

After the first surgery, the animals were kept in the lab for a period of 21 days. Following this period, the rats underwent an additional operation. An inventory of the peritoneal cavity was taken using a digital pachymeter to identify the success of the autotransplantation, followed by a volume calculation using the following formula: [4 $\pi$ (lenght/2)x(width/2)x(hight/2)/3 $]^{11}$. Classification of the experimental endometriosis implant growth was performed ${ }^{9}$, and only those animals that progressed to a growth score of III remained in the study (Figure 2).

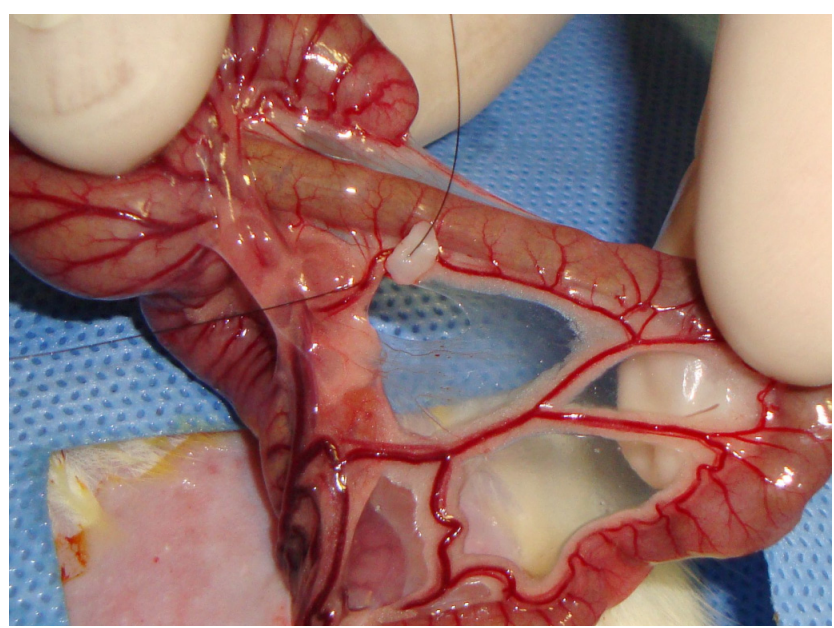

FIGURE 1 - Photomicrography showing construction of autotransplant according to Nogueira et al. ${ }^{1}$ 


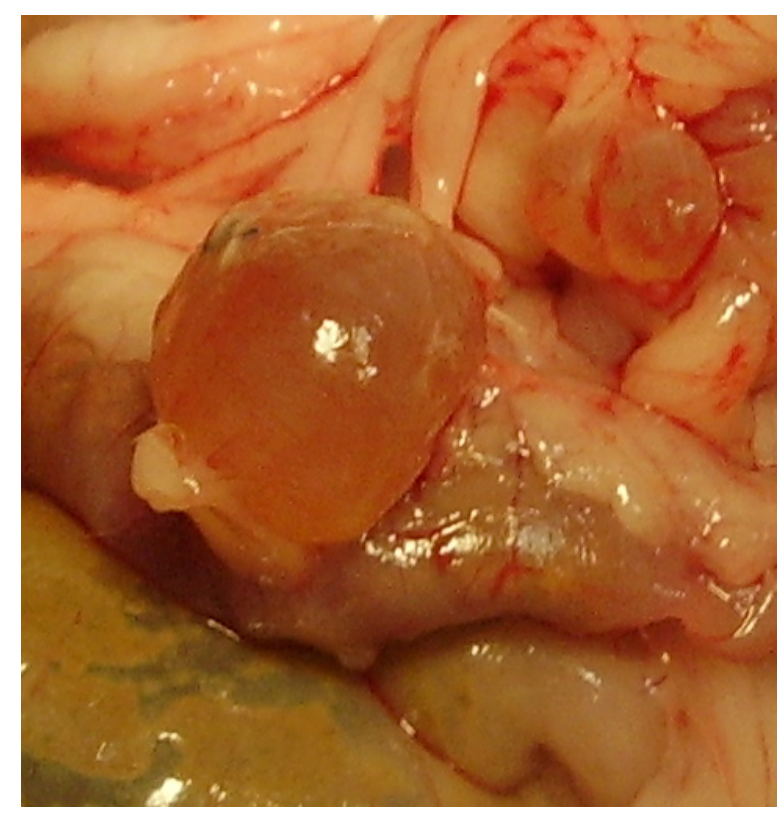

FIGURE 2 - Photomicrography showing an autotransplant with a diameter longer than $4.5 \mathrm{~mm}$, classified as grade III according to Quereda et al. ${ }^{9}$

After the surgical approach, the rats were identified and randomly divided into the Copaiferalangsdorffii (COP group) and the control group (C group), both containing 12 rats.

The COP group gavaged oil (Óleo de Copaiba ${ }^{\circledR}$ All Chemistry, lot 34883, São Paulo, Brazil) at $0.63 \mathrm{mg} /$ day for 14 days was carried out for Brito et al. in $2000^{12}$. The $\mathrm{C}$ group received $1 \mathrm{ml}$ daily gavage of $0.9 \%$ saline solution for 14 days.

After the end of the medical treatments, the rats were anesthetised using ketamine, and a third laparotomy was performed.

After opening the abdominal wall, an inventory of the peritoneal cavity and measurements of autotransplant volumes were performed; the transplant and the middle third of the uterine horn remaining were then removed. The salvaged tissue was rinsed with $0.9 \%$ saline solution and stored in $10 \%$ formaldehyde buffer for later anatomopathological analysis.

Paraffin tissues were sectioned in $5 \mu \mathrm{m}$ widths and placed in a warm bath; the slides were incubated with Meyer albumin and dried afterwards. Tissue sections were stained with hematoxylin-eosin (HE), and a histological analysis was performed by a pathologist. The oestrous cycles were analyzed in the middle third of the uterine horn remaining and drug efficacy was evaluated $^{10}$. The persistence of epithelial cells in uterine autografts was evaluated as follows: a well-preserved epithelial layer $=$ score 3 , a moderately-preserved epithelium with leukocyte infiltrate $=$ score 2, a poorly-preserved epithelium (occasional epithelial cell only) $=$ score 1 , and no epithelium $=$ score 0 (Figure 3$)$.

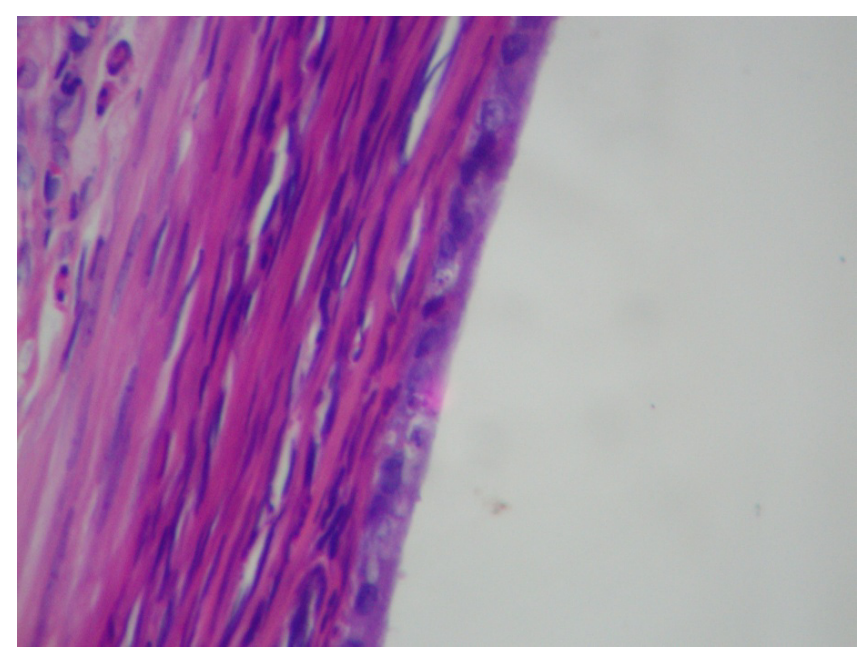

FIGURE 3 - Photomicrography of moderately-preserved epithelium, with mildly-preserved (40X) cytoplasm from the group of rats treated with $0,63 \mathrm{mg} /$ day Copaiferalangsdorffii, administered for a 14-day period.

Biostat 3.0 Windows XP was used for statistical analysis, where the significance level $(\alpha)$ used to reject the null hypothesis was $5 \%(p<0.05)$. The Mann-Whitney test was used for independent samplings, and the Wicoxon test was performed for related samples. Fisher's exact test was used to analyze the histopathologic score.

\section{Results}

Initially there were 12 samples in each group. Due to technical problems, one sample of the experimental group was lost. This left 11 samples in the experimental group. All of the middle third of the uterine horn remaining was in either the proestrus or oestrus phase of oestrous cycle.

There was no significant difference between the mean volume $\left(38.09 \mathrm{~mm}^{3}\right)$ in the $\mathrm{C}$ group and $\left(47.00 \mathrm{~mm}^{3}\right)$ that in the COP group at 21 days following the induction of endometriosis $(\mathrm{p}=0.470)$. Two weeks after administering copaiba oil and saline solution, the final average volumes were $65.40 \mathrm{~mm}^{3}$ for the $C$ group and $23.38 \mathrm{~mm}^{3}$ for the COP group $(\mathrm{p}=0.007)$.

Average volumes for the initial control group and the saline-treated group two weeks later were $38.09 \mathrm{~mm}^{3}$ and $65.70 \mathrm{~mm}^{3}$, respectively. This increase in average volume was significantly different $(\mathrm{p}=0.012)$. For the COP group, the initial average volume was $47.00 \mathrm{~mm}^{3}$, in contrast to the $23.38 \mathrm{~mm}^{3}$ final average, and these measurements were also significant $(\mathrm{p}=0.016)$ (Table 1). 
TABLE 1- Characteristics and results for a group of rats treated orally for 14 days with Copaiba oil $(0,63 \mathrm{mg} /$ day $)$ or saline solution $(1 \mathrm{ml} / 100 \mathrm{~g}$ body weight $)$.

\begin{tabular}{|c|c|c|c|}
\hline Group & Average Initial Volume & Average Final Volume & $p^{*}$ \\
\hline Oil copaiba & $47.00 \mathrm{~mm}^{3}$ & $23.38 \mathrm{~mm}^{3}$ & 0.016 \\
\hline Control & $38.09 \mathrm{~mm}^{3}$ & $65.40 \mathrm{~mm}^{3}$ & 0.012 \\
\hline $\mathrm{p}^{* *}$ & 0.470 & 0.007 & \\
\hline \multicolumn{4}{|c|}{$\begin{array}{l}\mathrm{p}^{*} \text { The Wilcoxon Test for samples (with } \mathrm{p}<0.05 \text { for rejecting the null hypothesis) comparing } \\
\text { averages of the initial and final volumes between the groups. }\end{array}$} \\
\hline \multicolumn{4}{|c|}{$\begin{array}{l}\mathrm{p}^{* *} \text { Mann-Whitney test for independent samples (with } \mathrm{p}<0.05 \text { for rejecting the null } \\
\text { hypothesis) comparing averages of the initial and final volumes between the oil copaiba } \\
\text { and the control treated groups. }\end{array}$} \\
\hline
\end{tabular}

Regarding preservation of the epithelial layer, upon histological evaluation of the autotransplant focus the experimental group $(\mathrm{n}=11)$ contained six cases $(55.00 \%)$ with a well-preserved epithelial layers (Figure 2), and five cases (45.00\%) with mildly-preserved epitheliums. The control group $(\mathrm{n}=12)$ included seven cases $(58.30 \%)$ with well-preserved epithelial cells and five cases $(41.70 \%)$ of mildly-preserved epithelial cells. No significant differences were presented $(\mathrm{p}>0.05)$.

\section{Discussion}

The treatment of endometriosis is either clinical or surgical or both. The drugs commonly used interfere with the menstrual cycle, and after the drug taking is suspended, there is a reoccurrence of the pathology. Although the surgeries can be simple, they are often mutilating. It is important to do the experimental tests with therapeutic options that go against what has happened in pathogenesis of endometriosis, mainly in the interference of the inflammatory process and oxidative stress ${ }^{1}$.

The copaiba oil is extracted from trees of the species Copaifera, popularly known as "copaiba", "copaíva" or "pau-deóleo". It is known to have the following medicinal qualities: antiinflammatory; anti-tumoral against Walker sarcoma and melanoma cell line; anti-ulcerogenic, antioxidant and anti-lipoperoxidative; cercaricide and anti- helmintic; insect repellent and antimicrobial. The cosmetic industry uses copaiba oil in shampoos, capillary lotion and bathing foams ${ }^{6}$.

The copaiba oil used in this research was extracted from the species Copaiferalangsdorffii, which has scientifically confirmed anti-inflammatory and antioxidant effects ${ }^{4,7}$, justifying its experimental use in endometriosis.

The doses used in this research were based on studies that used the copaiba oil in different doses $(0.63 \mathrm{ml} / \mathrm{kg}$ and 0.06 $\mathrm{ml} / \mathrm{kg}$ during 14 days), followed by microscopic hepatic evaluation of the rats, in which no hepatocelular alteration was found. The volume used in the pilot plan was $1.26 \mathrm{ml} / \mathrm{kg}$ during 14 days, where on the $5^{\text {th }}$ day $90 \%$ of the samples died. The volume was fractioned to $0.98 \mathrm{ml} / \mathrm{kg}$ ((3/4 de $1.26 \mathrm{ml} / \mathrm{kg}), 0.63 \mathrm{ml} / \mathrm{kg}\left({ }^{1} / 2\right.$ of $\left.1.26 \mathrm{ml} / \mathrm{kg}\right)$ and $0.31 \mathrm{ml} / / \mathrm{kg} 1 / 4$ de $1,26 \mathrm{ml} / \mathrm{kg}$ ). This way, the doses of 0.63 $\mathrm{ml} / \mathrm{kg}$ was standardized, representing the highest volume from which there were no mortalities in the period of 14 days, and considered sufficient to realize the major part of the experiment that used copaiba oil ${ }^{12}$. Our research reassured the security of the mentioned doses as there were no mortalities in our study.

Statins represent a class of drugs that can effectively decrease the serum level of cholesterol and is largely used in the treatment of hypercholesterolemia. Experimental studies show that these drugs effectively decreased the inflammatory processes and are anti-oxidant, and so were used in endometriosis experiments with similar methodology employed in this research. The sinvastatin used in the dose of $20 \mathrm{mg} / \mathrm{kg} /$ day during 14 days showed a significant regression of the focus of autotransplants when comparing the final volumes between the experimental and the control group ${ }^{1}$. Studies that used atorvastatin in high doses showed similar results ${ }^{13}$; results that are compatible with our research on copaiba oil.

Melatonin is the product of the secretion of the pineal gland whose main function is regulating sleep, but also has anti-inflammatory, antioxidant and immunomodulator properties. It was used in an experimental endometriosis rat model treated with melatonin $(10 \mathrm{mg} / \mathrm{kg})$ intraperitoneally, with the evaluation of the morphology of the autotransplants, the expression of COX-2 and antioxidants enzymes. After four weeks of treatment it showed significant reduction of the autotransplant volumes, COX-2 and antioxidant activities in the experimental group ${ }^{14}$. The morphological evaluation with the significant reduction in volume agreed with our results.

Strong evidence of the anti-inflammatory effect in the reduction of the volume of the focus of the autotransplants in rat model endometriosis is proven in studies that use dexametason $(0.8 \mathrm{mg} / \mathrm{kg} /$ day $)$ for 13 days in Wistar rats. The dexametason significantly reduced inflammatory processes, the amount of collagen in the stroma, and the area occupied by the glands of the autotransplants $^{15}$.

The histological evaluation didn't show compatible alterations with what was seen macroscopically without significant alterations. The use of melatonin showed significant histological changes in the experimental group when compared to the control group, but the author himself criticizes this type of evaluation because it is semi quantitative ${ }^{14}$.

The similar volume reduction of the copaiba oil when compared to anti-inflammatory, anti-oxidants and even imunommodulators confirmed the theoretical suspicion of the possible action against the development of focus of experimental endometriosis and opens one more possible line of research for the treatment of endometriosis. 


\section{Conclusion}

The copaiba oil, at least of the species Copaiferalangsdorfii, seems to be a promising therapeutic option in the clinical treatment of endometriosis.

\section{References}

1. Nogueira NJ, Torres OJM, Borges MOR, Coelho TM, Nascimento AGPAC, Nunes JJNN. Changes in the volume and histology of focus of endometriosis in rats treated with sinvastatin. Rev Bras Ginecol Obstet. 2007;29:396-402.

2. Montes LV, Broseghini LP, Andreatta FS, Sant'Anna ES, Neves VM, Silve AG. Evidences for the use of copaiba oil-resin in wound healing- a systematic review. Natureza Online. 2009;7:61-7.

3. Paiva LAF, Alencar Cunha KM, Santos FA, Gramosa NV, Silveira ER, Rao VSN. Investigation on the wound healing activity of oleo-resin from Copaiferalangsdorffii in rats. Phytother Res. 2002;16:737-9.

4. Paiva LAF, Gurgel LA, Silva RM, Tomé AR, Gramosa NV, Silveira ER, Santos FA, Roa VSN. Anti-inflamatory effect of kaurenoic acid, a diterpene from Copaiferalangsdorffii on acetic acid-induced colitis in rats. Vasc Pharmacol. 2003;39:303-7.

5. Vieira Junior VF, Rosas EC, Carvalho MV, Henriques MGMO, Pinto AC. Chemical composition and anti-inflammatory activity of copaíba oils from Copaiferacearensis Huber ex Ducker, Coipaifera reticulate Ducker and Copaiferamultijura Hayne - A comparative study. J Ethnopharmacol. 2007;112:248-54.

6. Gomes NM, Rezende CM, Fontes SP, Matheus ME, Fernandes PD. Antinociceptive activity of Amazonian Copiaba oils. J Ethnopharmacol. 2007;12;109:486-92.
7. Paiva LAF, Gurgel LA, Campos AR, Silveira ER, Roa VSN. Attennuation of ischemia/reperfusion-induced intestinal injury by oleo-resin from Copaiferalangsdorffii in rats. Life Sci. 2004;75:1979-87. 8. Santos SO, Ueda-Nakamura T, Dias Filho BP, Viegas Junior VF, Pinto AC, Nakamura CV. Effect of Brazilian copaíba oils on Leishmaniaamazonensis. J Ethnopharmacol. 2008;120:204-8.

9. Quereda F, Barroso J, Acien P. Individual and combined effects of triptoreline and gestrinone on experimental endometriosis in rat. Eur J Obstet Gynecol Reprod Biol. 1996;67:35-40.

10. Keenan JA, William-Boyce PK, Massey PJ, Chen TT, Caudle MR, Bukovsky A. Regression of endometrial explants in a rat model of endometriosis treated with the immune modulators loxoribine and levamisole. Fertil Steril. 1999;72:135-41.

11. Kudon M, Susuki Y, Ideyama Y, Nanya T, Mori M, Shikama H. Inhibitory effects of a novel aromatase inhibitor, YM511, on growth of endometrial explants and insulin-like growth factor $-\mathrm{I}$ gene expression in rats with experimental endometriosis. J Steroid Biochem Mol Biol. 1997;63:75-80.

12. Brito MVH, Oliveira RVBO, Silveira EL, Reis JMC, Noguchi A, Epaminodas WA, Morais MR. Microscopic aspects of the rats liver after copaíba oil administration. Acta Cir Bras. 2000;15:29-33.

13. Oktem M, Esinler L, Eroglu D, Haberal N, Bayraktar N, Zeyneloglu HB. High-dose atorvastatin causes regression of endometriotic implants: a rat model. Hum Reprod. 2007;22:1474-80.

14. Guney M, Oral B, Karahan N, Mungan T. Regression of endometrial explants in a rat model of endometriosis treated melatonin. Fertil Steril. 2008;89:34-42.

15. Batista APB, Medeiros PL, Texeira AAC, Teixeira VW. Histochemical and morphometric analysis of endometriotic lesions induced in female rats and treated with dexametasona. J Bras Patol. 2009;45:147-53.

\section{Correspondence:}

João Nogueira Neto

Av. dos Holandeses S/N Qd 24 Lote 05/901

65071-380 São Luís - MA Brasil

j.nogueira.n@uol.com.br

Conflict of interest: none

Financial source: none

${ }^{1}$ Research performed at Experimental Surgery Laboratory, University Hospital, Federal University of Maranhao (LACEMA-HUUFMA), Brazil. Presented at the XII National Congress on Experimental Surgery of the Brazilian Society for Development of Research in Surgery-SOBRADPEC, 2011 October 26-29 Ribeirao Preto-SP, Brazil. 